Che Zarrina, Nurul Salikin, Syed Mohammad \& Mohd Khairul Naim, "Emotional Stimuli on Intellect Among Older Adults," Afkār Vol. 21 Issue 1 (2019): 163-198

\title{
EMOTIONAL STIMULI ON INTELLECT AMONG OLDER ADULTS FROM ISLAMIC PSYCHOSPIRITUAL PERSPECTIVE
}

\section{Che Zarrina Sa'ari*, Nurul Salikin Sa'ari**, Syed Mohammad Hilmi Syed Abdul Rahman*, Mohd Khairul Naim Che Nordin*\#}

*Department of 'Aqidah \& Islamic Thought. Academy of Islamic Studies. University of Malaya. 50603. Kuala Lumpur. Malaysia.

${ }^{* *}$ The Centre for Human Brain Health. School of Psychology. College of Life and Environmental Sciences. University of Birmingham. Edgbaston. Birmingham. B15 2TT. United Kingdom.

Email: *\#khairulnaim@um.edu.my

DOI: https://doi.org/10.22452/afkar.vol21no1.6

Khulasah
Makalah ini membincangkan kesan rangsangan emosi
kepada intelek warga emas dari perspektif
Psikospiritual Islam. Kajian ini menjelaskan jenis
intelek, emosi dan rangsangan emosi dengan memberi
fokus kepada tiga rangsangan iaitu organ deria (hiss),
kognitif atau akal ('aql) dan hati (qalb). Adalah
dicadangkan rangsangan emosi yang positif digunakan
kepada warga emas untuk meningkatkan perhatian dan
emosi mereka. Kajian menggunakan kaedah kajian
literatur dalam pengumpulan data dan analisis
deskriptif dalam menganalisis data. Dapatan kajian
menunjukkan jenis rangsangan emosi yang positif
seperti memvisualisasi tanda kekuasaan Allah,
mendengar sesuatu yang baik, menghafal dan
memahami ayat-ayat al-Qur'an, berzikir dan berdoa
mampu memberi memberi impak kepada intelek
warga emas. Justeru, warga emas yang lebih kerap
memvisualisasi, mendengar, menghafal dan menyebut
rangsangan-ransangan emosi positif yang
dicadangkan, maka ingatan mereka akan semakin


Che Zarrina, Nurul Salikin, Syed Mohammad \& Mohd Khairul Naim, "Emotional Stimuli on Intellect Among Older Adults," Afkār Vol. 21 Issue 1 (2019): 163-198

kuat. Mereka juga akan merasai kedamaian, kebahagiaan, ketenangan dan kepuasan.

Kata kunci: Rangsangan emosi; intelek; kognitif; warga emas; Psikospiritual Islam.

\begin{abstract}
The article discusses impact of emotional stimuli on older adults' intellect from Islamic psychospiritual perspective. The study elaborates intellect, emotion and emotional stimuli types with focuses on three stimulus that are sensory organ (hiss), cognitive or mind ('aql) and heart (qalb). It is suggested the positive emotional stimuli to be applied on older adult to enhance their attention and emotion. In collecting data, the study employs the method of literature review and uses the descriptive analysis in analysing data. The finding shows the positive emotional stimuli types comprising seeing the signs of Allah's powerful, hearing good things, memorising and understanding the Quranic verses and reciting the dhikrullah and prayers will have impact on older adults' intellect. It suggests that the more often older adults visualise, listen, memorise and recite the suggested positive emotional stimuli, the stronger their memory becomes. They also appear to have a peace and happy mind, tranquillity and satisfaction.
\end{abstract}

Keywords: Emotional stimuli; intellect; cognitive; older adults; Islamic Psychospiritual.

\title{
Introduction
}

The article discusses the effects of emotional stimuli on human cognitive or intellect from Islamic psychospiritual aspect. Thus, it talks about intellect in the tradition of Islam, intellect among older adults, emotional stimuli and how emotional stimuli can significantly effect on older adults' intellect to produce perception. The study on this issue is vital in the field of psychospiritual because it can contribute to enhancing the satisfaction life of older adults. 
Che Zarrina, Nurul Salikin, Syed Mohammad \& Mohd Khairul Naim, "Emotional Stimuli on Intellect Among Older Adults," Afkār Vol. 21 Issue 1 (2019): 163-198

\section{Intellect in the Islamic Tradition}

One of the most important concepts discussed in Islamic thought is the Arabic term al-'aql. The term has several meanings as mentions by Ibn Manzuūr; intelligence, understanding, reason, intellect and cognitive. ' $A q l$ became the messenger of multiple overlapping or divagating meanings, it assumed particular influence in ethics, humanistic studies (adāb), prosody and rhetoric, law, theology, philosophy, in addition to in spiritual and metaphysical speculations. ${ }^{2}$

To explain intellect, Crow mentions there are several thoughts that could be taken. For instance, during the ancient and medieval worlds, intellect was regularly defined in practical terms as an inborn trait or faculty of the person. Alternatively, in a more theoretical view, intellect is described as a non-spatial substance that is original to the incorporeal realm of existence, while simultaneously creating part of the human soul with the capacity for grasping knowledge and utilising cognition. ${ }^{3}$ Intellect involves the distinction between inborn ideas as a path for understanding and a cognitive function, and that of acquired knowledge that need both sensory experiences revealed guidance, in addition to formal rational-cognitive procedures in getting the truth. Other than that, the intellect with the affective or emotional and intentional reality of ethical action was always intimately connected at the level of conscience and will and was regarded central to selfawareness and consciousness. ${ }^{4}$

${ }^{1}$ Ibn Manẓūr, Lisān al- 'Arab, vol. 11 (Beirut: Dār Șādir, 1414H), 458.

${ }^{2}$ Karim Douglas Crow, "The Intellect in Islamic Thought: Mind and Heart," KATHA : The Official Journal of the Centre for Civilisational Dialogue, Vol. 2 No. 1 (2006), 1.

${ }^{3}$ Ibid., 2.

${ }^{4}$ Mohamed Safiullah, "The Soul (Heart) and Its Attributes: An Islamic Perspective with Reference to Self in Western Psychology," Journal of Aqidah and Islamic Thought (AFKAR) Vol. 16 (2015), 107; Yusuf 
The intellect as clarified by Crow is frequently defined as a mental faculty in contemporary understanding. It is a division of the human mind having a distinguished capacity for knowledge in contrast to sense experience. However, current belief of intellect and mind almost without fail adopt a physicality brain or bodily conception. As for instance, a study that stress the biological basis of cognition, specifically cognitive psychology based on empirical bio-genetic and neurophysiological studies, by investigate the neurophysiology of meaning-perception in humans. ${ }^{5}$

The different notion can be seen in the field of Islamic psychospiritual. The Qur'an as one of the main sources of Islamic teachings has touched on to the uniqueness of men as a rational and intelligent beings distinguished from other creatures. The Qur'an alludes that men have been bestowed with a superb intellect or cognitive tract, power of speech, reasoning and free will. ${ }^{6}$ Thus, they are ready to receive and comprehend knowledge. Allah the almighty says: ${ }^{7}$

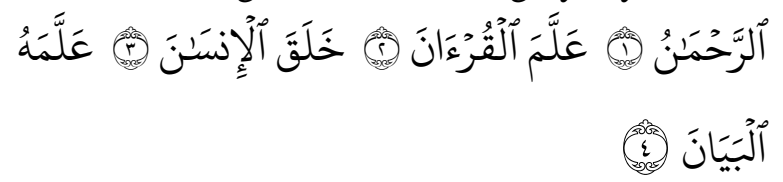

The Beneficent Allah. Taught the Quran. He created man. Taught him the mode of expression.

The Qur'an also states that consequent endowed men with intellect that they have been elevated upon all other

Dalhat, "The Concept of al-Aql (Reason) in Islam", Internatioal Journal of Humanities and Social Science Vol. 5 No. 9(1) (September 2015), 77-78.

${ }^{5}$ Crow, The Intellect in Islamic Thought: Mind and Heart, 2.

6 Salisu Shehu, "A Study of the Islamic Perspective of Cognitive Development and Its Implications in Education in the Muslim World," Revelation and Science Vol. 5 No. 1 (2015), 4.

${ }^{7}$ Al-Qur'an, Surah al-Rahman 55:1-4. 
creatures and that the whole universe has been subjected to their use, as Allah says: ${ }^{8}$

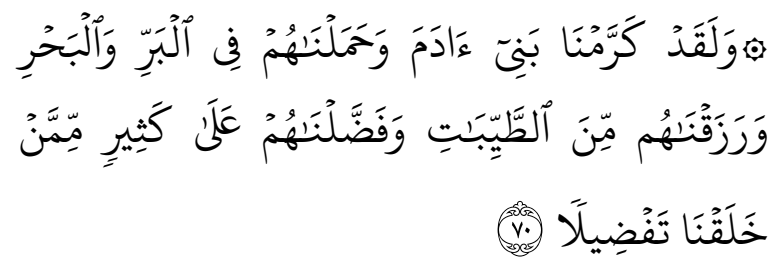

And surely, We have honoured the children of Adam, and We carry them in the land and the sea, and We have given them of the good things, and We have made them to excel by an appropriate excellence over most of those whom We have created.

Armstrong in Sufi Terminology describes 'aql as intellect.' 'Aql from the perspective of Islamic psychospiritual can be referred to al-Ghazāli as he divided it into two meanings. First meaning refers to the intellect or the medium through which the true nature of the material things is known, and its seat is in the soul. Second meaning alludes to the power to understand the secrets of different learnings, where it is termed a subtle essence manifested as knowledge, which is contained within the intellect. ${ }^{10}$ These two aspects, one with a material base and the other immaterial, are interdependent. Islam affords a prime place to the intellect, which also includes reason, the ability to discern between right and wrong, good and evil, the real

\footnotetext{
${ }^{8}$ Al-Qur'an, Surah al-Isra' 17:70.

${ }^{9}$ Amatullah Armstrong, Sufi Terminology (Al-Qamus al-Sufi) (Lahore: Ferozsons, 2001), 32.

10 Abū Hāmid Muhammad bin Muhammad al-Ghazālī al-Ṭūsī, Ihyya Ulūm-Id-Dìn, trans. M. F. Karim, vol. 3 (New Delhi: Islamic Book Services, 1995), 5; Mohamed Safiullah, "The Soul (Heart) and Its Attributes", 100-101.
} 
and the illusory, all of which enable man to get nearer to the Creator. ${ }^{11}$ The Qur'an says: ${ }^{12}$

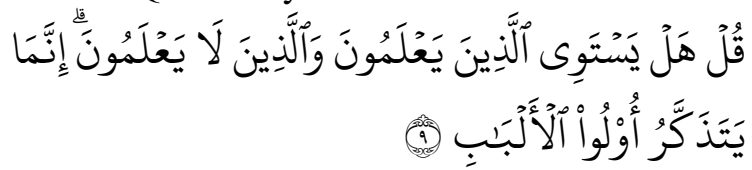

Say: Are those who know and those who do not know alike? Only the men of understanding are mindful.

Furthermore, the different between those who are ignorant or those whose heart are blind and those who are wise or whose heart are seeing has been stated in the Qur'an, together with a metaphor of the darkness is not like the light, as Allah says: ${ }^{13}$

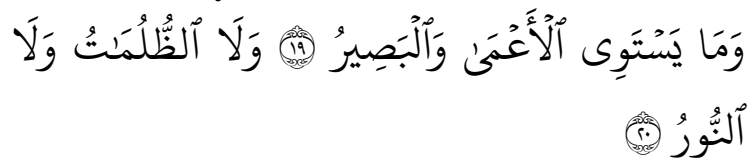

And the blind and the seeing are not alike. Nor the darkness and the light.

To elaborate this, the view of al-Ghazāli in pointing out four distinct meanings for ' $a q l$ relate to the knowledge would be explored. First, the ability of human beings to understand and grasp the theoretical sciences (nazariyah), while being able to master the abstract discipline (fikriyyah). Second, refers to the knowledge which is instinctual that manifests in infants, with their ability to discern things; third, that which is acquired through experience (empirical knowledge) during the course of time; and fourth, the power of instinct that is so highly

${ }^{11}$ Frithjof Schuon, Sufism: Veil and Quintessence, A New Translation with Selected Letters, ed. James Cutsinger (Bloomington, Indiana: World Wisdom, 2006), 23;

${ }^{12}$ Al-Qur'an, Surah Zumar, 39:9.

${ }^{13}$ Al-Qur'an, Surah Fāṭir 35, 19-20. 
developed that one is able to predict or forecast, even though the accuracy of which ranges given that only God has absolute knowledge. ${ }^{14}$

In Islam, a sound and matured intellect has always been made a precondition to all religious obligations (taklif). In some cases, it becomes a precondition to the validity of discharging them. No man in Islam is obliged to undertake any form of religious obligation compulsorily unless one is adequately mentally developed or sound. The implication of this is that young men who are not mentally developed and cannot independently and decisively differentiate the good from the bad are not held responsible for their actions. Thus, in Islam determines that no sin is consequently recorded against those men for all their actions. ${ }^{15}$ The same thing applies to the sleeper, insane, and or the mentally retorted who are considered unmindful. ${ }^{16}$ Prophet Muhammad PBUH says:

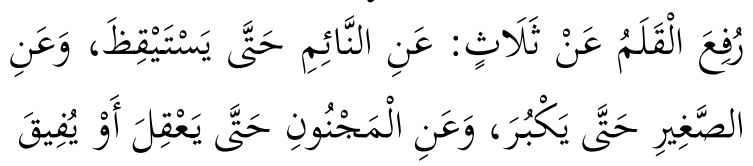

The pen (for record of sins) has been lifted from writing the deeds of three (persons), the ones who asleep until he awakes, a small child until

\footnotetext{
${ }^{14}$ Nabih Amin Faris (Trans. with Notes), Imam al-Ghazali, The Book of Knowledge (New Delhi: Islamic Book Services, 1991), 218-220; Mohamed Safiullah Munsoor \& Che Zarrina Saari, "Knowledge and Islam on the Non-Rational and Rational-Heart-Brain InterConnection", Journal of Aqidah and Islamic Thought (AFKAR), Vol. 19(1) (2017), 134-135.

15 Salisu Shehu, "A Study of the Islamic Perspective of Cognitive Development", 4.

${ }^{16}$ Yusuf Dalhat, "The Concept of al-Aql (Reason) in Islam", 81.
} 
Che Zarrina, Nurul Salikin, Syed Mohammad \& Mohd Khairul Naim, "Emotional Stimuli on Intellect Among Older Adults," Afkār Vol. 21 Issue 1 (2019): 163-198

he reaches puberty, and the insane until he regains sanity. ${ }^{17}$

And this is evidenced by the fact of al-Qur'an raised about small children who have not reach their puberty or have not yet attained matured intellectual development that in the first verse, only three occasions in which people customarily rest were specified for seeking permission. However, there was no exception as to the time for seeking permission in the second verse because they have now come to the age of maturity both physically and mentally. ${ }^{18}$ Allah says: ${ }^{19}$

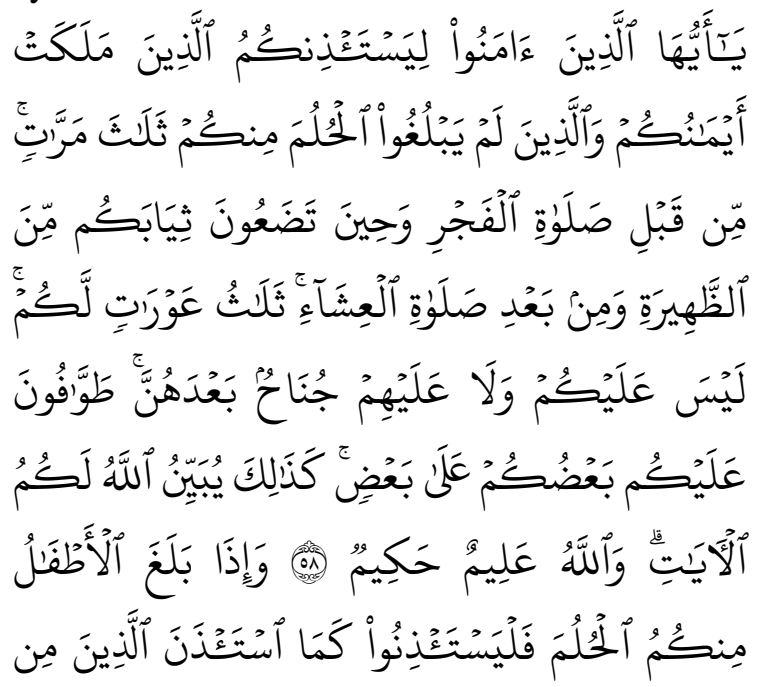

${ }^{17}$ Abū 'Abd al-Raḥmān Aḥmad bin Shu'īb, al-Nasā'i, al-Mujtabā min al-Sunan, tahqiq 'Abd al-Fattāḥ Abū Ghuddah, Bāb Man Lā Yaqa'u Talāquh min al-Azwāj, No. 3432, Vol. 6 (Halab: Maktab al-Maṭbū'āt al-Islāmiyyah, 1986), 156.

18 Salisu Shehu, "A Study of the Islamic Perspective of Cognitive Development", 4; Crow, The Intellect in Islamic Thought: Mind and Heart, 8-9.

${ }^{19}$ Al-Qur'an, Surah al-Nur 24:58-59. 


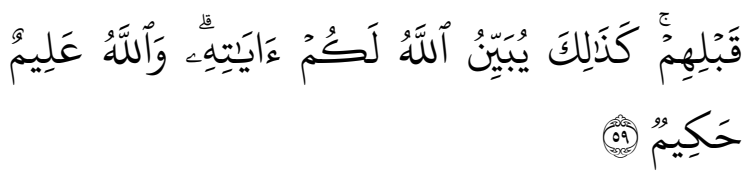

O you who believe! Let those whom your right hands possess and those of you who have not attained to puberty ask permission of you three times; before the morning prayer, and when you put off your clothes at midday in summer, and after the prayer of the nightfall; these are three times of privacy for you; neither is it a sin for you nor for them besides these, some of you must go round about (waiting) upon others; thus does Allah make clear to you the communications, and Allah is Knowing, Wise. And when the children among you have attained to puberty, let them seek permission as those before them sought permission; thus, does Allah make clear to you His communications, and Allah is knowing, Wise.

The situation shows Islam recognises the gradual process in gaining intellectual maturity (cognitive development). For that reason, means that the notion of cognitive development has a firm basis in Islam and that it follows through certain stages to develop to its fullest stage of development. ${ }^{20}$

On top of that, many of the Qur'anic verses emphasizes the importance of knowledge and encourages or even challenges men to make good use of power of reasoning and cognition to obtain sound and factual knowledge, particularly in knowing Allah (ma'rifatullah)

${ }^{20}$ Salisu Shehu, "A Study of the Islamic Perspective of Cognitive Development", 4; Crow, The Intellect in Islamic Thought: Mind and Heart, 8-9. 
Che Zarrina, Nurul Salikin, Syed Mohammad \& Mohd Khairul Naim, "Emotional Stimuli on Intellect Among Older Adults," Afkār Vol. 21 Issue 1 (2019): 163-198

and His Glory. Allah usually makes the statements and asks men through His verses to reflect, think and understand.

At this point, Allah emphasizes on the function of heart (qalb) in acquiring and perceiving knowledge. For instance, Allah says: ${ }^{21}$

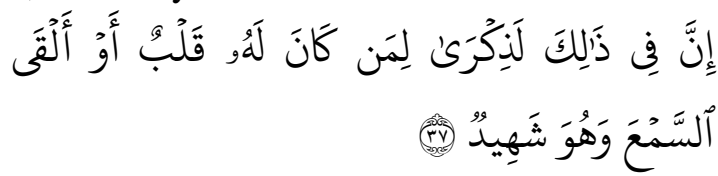

Most surely there is a reminder in this for him who has a heart ('aql), or he gives ear and is a witness.

And: ${ }^{22}$

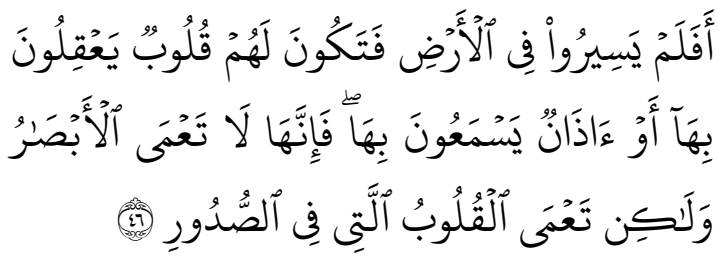

Have they, then never journeyed about the earth, letting their hearts gain wisdom, and causing their ears to hear? Yet, verily, it is not their eyes that have become blind - but blind have become the hearts that are in their breasts.

Al-Ghazāli in his works explains the heart has the power to transform something potential to something actual and forms a spiritual entity, known as al-rūhāniyyah. Given that the heart has varied states, it is called by different names, for example, when it is involved in intellectuality

${ }^{21}$ Al-Qur'an, Qaf 50:37.

${ }^{22}$ Al-Qur'an, al-Hajj 22:46. 
and learning it, is termed intellect, but when it governs the body it is called soul. ${ }^{23}$ Allah says: ${ }^{24}$

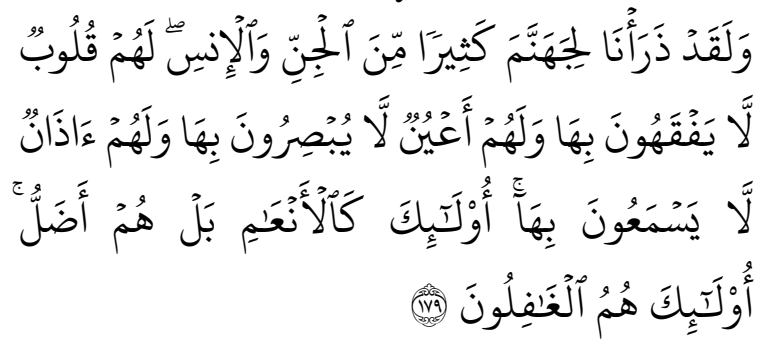

And certainly We have created for hell many of the jinn and the men; they have hearts with which they do not understand, and they have eyes with which they do not see, and they have ears with which they do not hear; they are as cattle, nay, they are in worse errors; these are the heedless ones.

In this regard, al-Muhāsibī corresponds the heart as the essence of the self, which is immaterial, controlling the conscious nature of man and an instrument, which enables reality to be perceived and interpreted. ${ }^{25}$

\section{Intellect Among Older Adults}

Islamic psychospiritual views on the cycle life of human being sticks to the general views of the Qur'an and the Prophetic Traditions. Allah says: ${ }^{26}$

\footnotetext{
${ }^{23}$ Syed Muhammad Naquib al-Attas, Prolegomena to the Metaphysics: An Exposition of the Fundamental Element of the Worldview of Islam, 2nd ed. (Kuala Lumpur: International Institute of Islamic Thought \& Civilization (ISTAC), 2001), 148.

${ }^{24}$ Al-Qur'an, Surah al-A'raf 7:179.

${ }^{25}$ Margaret Smith, Al-Muḥāsibi, An Early Mystic of Baghdad, translated and commentary by Margaret Smith (Lahore: Islamic Book Foundation.1935), 86.

${ }^{26}$ Al-Qur'an, Surah al-Hadid 57:20.
} 


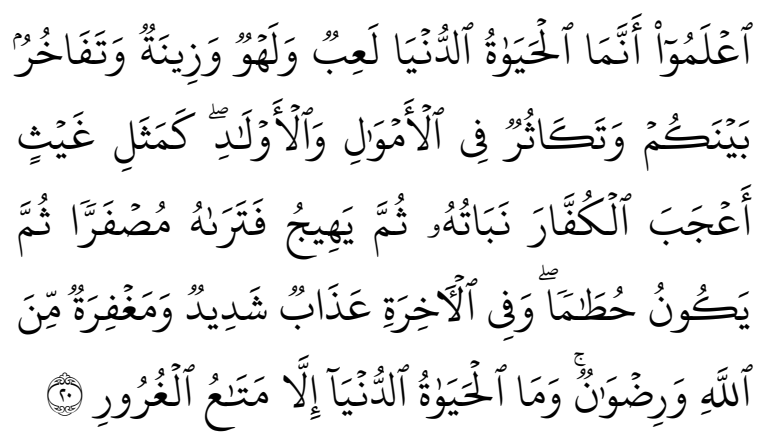

Know that this world's life is only sport and play and gaiety and boasting among yourselves, and a vying in the multiplication of wealth and children, like the rain, whose causing the vegetation to grow, pleases the husbandmen, then it withers away so that you will see it become yellow, then it becomes dried up and broken down; and in the hereafter is a severe chastisement and (also) forgiveness from Allah and (His) pleasure; and this world's life is naught but means of deception.

As mentioned in the above Qur'anic verse, the cycle life of every human being can be divided into several stages begins from womb life, baby life, children and youth life. Then, they will enter the stage of maturity in the ages of 40 to 60 years. ${ }^{27}$ This stage known as a stage of constancy in cognitive development. Although decline in cognitive functioning is assumed to start usually after 40 years, however, even if the weakening happens, their cognitive functioning is very subtle and hardly observable or noticeable. That is why this stage can be called as stage of sin al-tawaqquf (static age), that can be understood as a

27 Shulamith Shahar, Growing Old in the Middle Ages: Winter Clothes Us in Shadow and Pain (London and New York: Routledge, 2004), 13. 
stage within which no further progressive development or decline of mental functioning is recognisable. ${ }^{28}$ But a person's mental functions remain evidently normal at this stage. The basis of this assertion can be interpreted from the verses 37 of Chapter Fatir, as Allah says: ${ }^{29}$

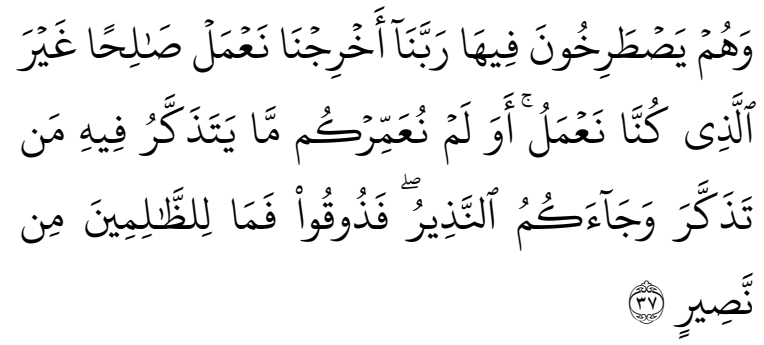

And they shall cry therein for succour: $\mathrm{O}$ our Lord! take us out, we will do good deeds other than those which we used to do. Did We not preserve you alive long enough, so that he who would be mindful in it should mind? And there came to you the warner; therefore taste; because for the unjust, there is no helper.

The verse mentioned human being who will be unfortunate to be destined to fire ( $a l-n \bar{a} r)$, will cry pleading to Allah to give them a second chance to live in order to do good deeds. However, Allah will ask them a question, which men should honestly ask themselves is the lifetime they have been given on earth, is not enough for them to study Allah's Book and take heed from it. In addition to that, the Prophet (SAW) was also reported by al-Bukhāri and others, on the authority of Abu Hurayrah to have said that: "Allah will not accept the excuse of any person whose

28 Salisu Shehu, "A Study of the Islamic Perspective of Cognitive Development," 7.

${ }^{29}$ Al-Qur'an, Surah Fatir 35:37. 
instant of death is delayed till he is sixty years of age." 30 These evidence confirmed the finding that human mental functions remain normal at this stage and in Islamic teaching men still responsible for executing God's commands and abandon His prohibitions.

Followed by this stage is the stage of old age where it begins from 60 to 80 years old known as sin alshaykhūkhah (old age). ${ }^{31}$ The above Prophetic Tradition provides the basis for distinguishing this stage. It is at this stage where human mental functioning starts to decline gradually and steadily. In verse 67 of Chapter al-Ghafir, Allah says: ${ }^{32}$

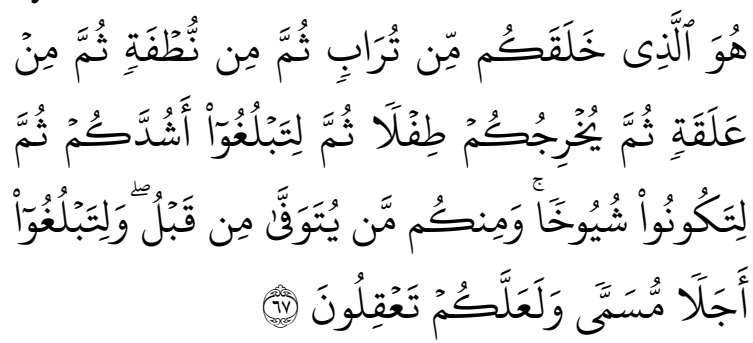

He it is Who created you from dust, then from a small life germ, then from a clot, then He brings you forth as a child, then that you may attain your maturity, then that you may be old and of you there are some who are caused to die before- and that you may reach an appointed term, and that you may understand.

30 Al-Bukhari, Sahih al-Bukhari, trans. M. Muhsin Khan, ed. Mika'il alAlmany, Vol. 8, Book 76, To Make The Heart Tender (ar-Riqaq), Number 428, Online Version, retrieved 21 June 2019, https://d1.islamhouse.com/data/en/ih_books/single/en_Sahih_AlBukhari.pdf,.

31 Salisu Shehu, "A Study of the Islamic Perspective of Cognitive Development," 7.

32 Al-Qur'an, Surah Ghafir 40:67. 
The Arabic word shuyükhan is used in this verse means old people. This verse specifically mentioned that it is an exclusive stage of its own different from another stage that comes after it where it begins from 80 years and above known as the stage feeblest old age or senescence (ard al'umur). It is the period with which mental degeneration becomes much more obvious particularly as age increases towards 100 years and above as ${ }^{33}$ mentioned in many verses of the Prophetic Tradition and the Qur'an: ${ }^{34}$

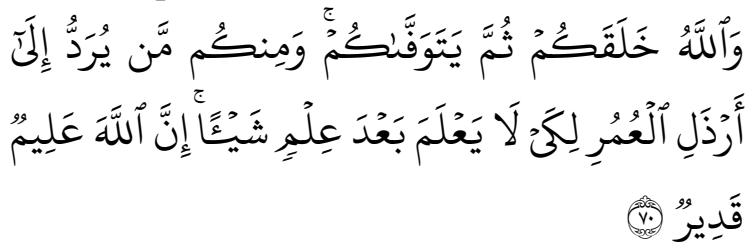

And Allah has created you, then He causes you to die, and of you is he who is brought back to the worst part of life, so that after having knowledge he does not know anything; surely Allah is Knowing, Powerful.

The verse revealed that men in this cycle will have a turning point to lose and forget the knowledge that has been learned and obtained before, and some of them also experience dementia. ${ }^{35}$ Perception and attention are two of the major functions that are impaired by age. Older adults suffer from problems in shifting attention, dividing attention and attentional inhibition. ${ }^{36}$ On the other hand,

33 Salisu Shehu. "A Study of the Islamic Perspective of Cognitive Development," 8.

${ }^{34}$ Al-Qur'an, Surah al-Nahl 16:70; Surah al-Hajj 20:5.

35 Șālih 'Abd al-'Azīz Muhammad al-Shaykh, al-Tafsīr al-Muyassar (Saudi Arabia: Majma' al-Mālik Fahd, 2009), 274.

${ }^{36}$ Elena Commodari \& Maria Guarnera, "Attention and Aging," Aging Clinical and Experimental Research, Vol. 20 No. 6 (December 2008), 578-584. 
Che Zarrina, Nurul Salikin, Syed Mohammad \& Mohd Khairul Naim, "Emotional Stimuli on Intellect Among Older Adults," Afkār Vol. 21 Issue 1 (2019): 163-198

aging is also associated with a decline in sensory processing. ${ }^{37}$ One hypothesis suggests that older adults may need to command greater attentional control to compensate for their declining of processing capacity. Based on the 'Load Theory', it can be argued that deteriorating executive processes lead to older adults operating with higher cognitive demands than younger persons, resulting in declining performance on many tasks. ${ }^{38}$ An alternative hypothesis suggests that aging is specifically associated with a decrease in inhibitory processes in which the ability to ignore a distractor is reduced. ${ }^{39}$ Both accounts predict that older adults will struggle to focus their attention on relevant items particularly when demands are placed on the ability to ignore irrelevant information.

The processing of emotional stimuli has also been reported to change with age. For example, some studies indicate that older adults are biased toward perceiving happy emotions ${ }^{40}$ and, so tend to remember proportionately more positive emotional stimuli, compared with younger persons. $^{41}$

37 Jonathan W. Page \& Michael A. Crognale, "Differential Aging of Chromatic and Achromatic Visual Pathways: Behavior and Electrophysiology," Vision Research Vol. 45 No. 11 (May 2005), 1481-1489.

38 Nilli Lavie, "Attention, Distraction, and Cognitive Control Under Load," Current Directions in Psychological Science, Vol. 19 No. 3 (June 2010), 143-148.

39 Jillian C. Sweeney \& Geoffrey N. Soutar, "Consumer Perceived Value: The Development of a Multiple Item Scale," Journal of Retailing, Vol. 77 (2001), 203-220.

${ }^{40}$ Katja Werheid et al., "Familiar Smiling Faces in Alzheimer's Disease: Understanding the Positivity-related Recognition Bias," Neuropsychologia, Vol. 49 No. 10 (Aug 2011), 2935-2940.

${ }^{41}$ Donna Rose Addis, Reece P. Roberts \& Daniel L. Schacter, “Agerelated Neural Changes in Autobiographical Remembering and Imagining," Neuropsychologia, Vol. 49 No. 13 (Nov 2011), 36563669 . 
Che Zarrina, Nurul Salikin, Syed Mohammad \& Mohd Khairul Naim, "Emotional Stimuli on Intellect Among Older Adults," Afkār Vol. 21 Issue 1 (2019): 163-198

\section{Emotional Stimuli Types}

Emotional stimuli theory has been discussed in the field of cognitive neuropsychology. According to Fridja ${ }^{42}$ and Scherer $^{43}$, most emotion theories hold that emotional stimulation typically represents a certain type of stimulus as it has a direct relationship with the survival of humans and their well-being. For example, some stimuli may indicate threats like predators or enemies, while other possible stimuli mean for growth and development purposes such as potential partner or food source.

Such stimuli require fast response, such as when it comes to the threat, then the response to avoid threats or approaching the positive stimulus should happen quickly. Emotional reactions are a form of adjusting responses to exciting stimulus, including the tendency to take action, body mass reactions, behavioural reactions and subjective feelings changes. This emotional stimulate provide a system for action while tolerating some flexibility in response. These emotional stimuli as Frijda and Scherer said are not associated with reflexes with certain reactions, but they relate to an emotion primes an arsenal of potential adaptive responses. ${ }^{44}$

Most emotion theories according to Ekman, ${ }^{45}$ argue that emotions act to manage adaptive responses to stimuli that are crucial for the purpose of human survival and their well-being. The basics of emotion theories take on different

42 Nico H. Frijda, "Passions: What Emotions Really Are?," in Personality, Human Development and Culture: International Perspective on Psychological Science 2, eds. Ralf Schwarzer \& Peter A. Frensch (Hove and New York: Psychology Press, 2010), 46.

${ }^{43}$ K. R. Scherer, "Emotion Serves to Decouple Stimulus and Response," in The Nature of Emotion: Fundamental Questions, eds. P. Ekman \& R. J. Davidson (New York: Oxford University Press, 1994), 127-130.

${ }^{44}$ Frijja, Passions: What Emotions Really Are?, 48; Scherer, Emotion Serves to Decouple Stimulus and Response, 127-130.

45 P. Ekman, "An Argument for Basic Emotions," Cognition and Emotion, Vol. 6(3/4), (1992), 170. 
fundamental emotions such as anger, fear, sadness, happiness, hatred or surprise. These basic emotions are defined by Ekman as effect of systems triggered by certain events to produce a specific emotional response pattern such as producing prototypical facial expressions as well as physiological responses. ${ }^{46}$ In addition, according to Panksepp, ${ }^{47}$ the situation is also driven by a certain nervous system response.

Basic emotion theories view that perceptual emotional stimuli process is believed to be regularly marked with innate categories being universally found in human beings. Thus, according to Ohman, Flykt \& Esteves, some theorists suggest a unique role for the basic emotion of fear. ${ }^{48}$ Hence, due to evolutionary factors, stimuli related to fear of a threat such as an expression of angry or surprised face when seen snake or scorpion is considered that the fearful emotion is attended, perceived, acknowledged, remembered and associated with faster adaptive behaviour or easier than any other emotional stimuli. Ellsworth \& Scherer explains assessment emotion theories propose that the emotional process of a human being is highlighted as the individual constantly evaluate objects, actions, events and conditions relating to their personal needs, aims, values and common well-being. $^{49}$

Individuals exhibit different emotional forms based on the subjective assessment of a stimulus or event occurrence

${ }^{46}$ Ibid., 170-172.

${ }^{47}$ J. Panksepp, Affective Neuroscience: The Foundations of Human and Animal Emotions (New York: Oxford University Press, 1998), 281.

48 Arne Ohman, Anders Flykt \& Francisco Esteves, "Emotion Drives Attention: Detecting the Snake in the Grass," Journal of Experimental Psychology: General, Vol. 130 No. 3 (2001), 466-467.

${ }^{49}$ P. C. Ellsworth \& K. R. Scherer, "Appraisal Processes in Emotion”, in Series in Affective Science: Handbook of Affective Sciences eds. R. J. Davidson, H. H. Goldsmith \& K. R. Scherer (New York: Oxford University Press, 2003), 573. 
on several standard criteria or based on predetermined objectives such as uniqueness, intrinsic satisfaction, beneficial aims, main interests and managing potential to overcome something that arises. The assessment of the response of these emotional stimuli is subjective. Hence, individual functions and specific situations cause emotional distinction between a race or ethnicity, age group, personality traits and cultural background. The results of different evaluation criteria are expected to promptly drive physiological responses, motor expressions and individual action forms. ${ }^{50}$

In this regard, Smith \& Lazarus explain that the emotion categories based on subjective experiences are to produce the pattern of reaction which can be categorized as modal emotions which reflects on the often-occurring situation that forms some patterns of the reactions associated with core concerns or core relational themes. ${ }^{51}$ The dimension approaches featured in dimensional theories of emotion allow negative and positive emotions of different intensities to be distinguished, reflecting the two basic motivational systems namely the appetite and aversive systems that trigger the approach and withdrawal of action. 52

Scholars who discuss theories of emotion emphasize the role of culture, language, and thought in the emergence of emotional experiences. Barrett suggests that the emotion categories are not natural entities inherent in humans, but it

${ }^{50}$ Scherer, Emotion Serves to Decouple Stimulus and Response, 127130

${ }^{51}$ C. A. Smith \& R. S. Lazarus, "Emotion and Adaptation", in Handbook of Personality: Theory and Research, ed. L. A. Pervin (New York: Guilford Press, 1990), 609-637.

52 R. J. Davidson \& W. Irwin, "The Functional Neuroanatomy of Emotion and Affective Style," Trends in Cognitive Science, Vol. 3 No. 1, 12-15. 
Che Zarrina, Nurul Salikin, Syed Mohammad \& Mohd Khairul Naim, "Emotional Stimuli on Intellect Among Older Adults," Afkār Vol. 21 Issue 1 (2019): 163-198

is a man-made concept. ${ }^{53}$ Thus, it can be learned, cultivated, nurtured and trained

In further, the scholars also discuss on how are emotion types determined? Across many languages, we find a large variety of types that we use to describe our emotional experiences. The empirical evidence and theoretical considerations indicate that emotion types are not principally determined universally or biologically but are learned and continuously adjusted in a flexible way. Grouping of different stimuli into an emotional type can be based on some different principles, reflecting the correlational structure of the environment, the optimisation of communicative goal attainment, the combination of a set of appraisal outputs, or the subjective emotional feeling elicited by a stimulus. Emotion types thus can be considered as adaptive and flexible emotion scripts, integrating aspects of emotion elicitation (appraisal, core relational themes) and the emotional response toward the emotional stimulus (bodily responses, motor responses, action tendencies, and subjective feeling). Some aspects of these may be relatively hard-wired, others mainly determined by culture. ${ }^{54}$

Regarding this matter, in Islamic psychospiritual, a well-known Muslim psychologist, Muhammad 'Uthmān Najati states that an internal reaction to something, experience or event embraces emotional diversity such as

53 L. F. Barrett, "Are Emotions Natural Kinds?" Perspectives on Psychological Science, Vol. 1 No. 1 (2006), 29-30.

${ }^{54}$ J. A. Russell \& B. Fehr, "Relativity in the Perception of Emotion in Facial Expressions," Journal of Experimental Psychology: General, Vol. 116 No. 3 (1987), 223-237; L. W. Barsalou, "Ideals, Central Tendency and Frequency of Instantiation as Determinants of Graded Structure in Types," Journal of Experimental Psychology: Learning, Memory, and Cognition, Vol. 11 No. 4 (1985), 629-654; P. M. Niedenthal, J. B. Halberstadt \& A. H. Innes-Ker, "Emotional Response Categorization," Psychological Review, Vol. 106 No. 4 (1999), 337-361. 
anger, sadness, sorrow, frustration, fear, joy and love. ${ }^{55}$ In fact, the presence of the Messenger of Allah (P.B.U.H.) has provided guidance to human beings to learn and understand emotional reactions and emotional management methods. If today's review of emotional intelligence, some of the key elements in emotional intelligence are recognizing the kind of emotions, understanding the emotions of others and the emotions of others, knowing how emotionally triggers and their impact on self-development and relationships.

Through the revelation and guidance of Allah, His Messenger has taught his people to recognize what is emotion. A variety of emotional reactions are described by Allah as angry, sad, sorrowful, happy, shy, fearful and nervous and so forth. For example, in the Qur'an that describes the sad and fear emotions as the word of Allah in Surah al-Baqarah verse 2:277 means, "Surely they who believe and do good deeds and keep up prayer and pay the poor-rate they shall have their reward from their Lord, and they shall have no fear, nor shall they grieve." While in relation to hate, Islam suggests that there is no hatred beyond human limitations, and at the same time instructs men to place such hatred on matters that can lead them to shirk, cruelty and disobedience. In the Qur'an, Allah says in surah al-Baqarah, verse 2:216, which means, "Fighting is enjoined on you, and it is an object of dislike to you; and it may be that you dislike a thing while it is good for you, and it may be that you love a thing while it is evil for you, and Allah knows, while you do not know."

As mentioned above, men individually expose different emotional forms based on the subjective stimulus constructed on predetermined objectives. In Islamic psychospiritual study as for example in the works of alGhazali, men are necessitated to work hard to attain

55 Muhammad 'Uthmān Najātī. Al-Dirasāt al-Nafsāniyyah 'Ind al'Ulamā' al-Muslimīn. (Cairo: Dār al-Shuruq, 1993), 76. 
happiness in this world as well as the hereafter. In order to attain this kind of happiness, men have to arrive at the level of piety $(\text { taqwa })^{56}$ and reach the stage of Ihsan. Considering these aims of Muslim lifes, Islam teaches men to mak use three levels of human perception, i.e. the sensory, intellectual and spiritual levels.

From that, it could be said that in modern psychological explanations of perception and cognition, the last level is absent. The cognitive organs in which all these three levels are the sensory organs (hiss); the mind/intellect/cognitive ( ' $a q l$ ); and the heart (qalb). Allah says in the Qur'an, means: ${ }^{57}$ "It is He (Allah) Who brought you forth from the wombs of your mothers when ye knew nothing: and He gave you hearing an sight and intelligence and affections: that ye may give thanks (to Him)". At the sensory level of perception, the organs involve are seeing, hearing, smelling, touching and tasting. Whilst, at the intellectual level, the intellect or cognitive involve through a process of cognition, reasoning and insight. Then, at the spiritual level the intellect or cognitive and the heart are involved. ${ }^{58}$ These sensory organs particularly seeing and hearing, intellect as well as heart become an important stimulus which respond to environmental stimuli to produce emotional stimuli types.

\section{Emotional Stimuli Types on Older Adults Intellect}

Maintaining healthy cognitive abilities is vital for the quality of life for older adults, especially in ageing people of modern times. Cognitive functions decline with advancing age in adulthood. This decline is manifested, for example, as a reduced ability to shift attention, poor memory performance and difficulties in problem-solving

\footnotetext{
${ }^{56}$ Among the verses are in Al-Qur'an, al-Baqarah 2:15, 76, 186, 198.

${ }^{57}$ Al-Qur'an, Surah al-Nahl 16:78.

58 Salisu Shehu, "A Study of the Islamic Perspective of Cognitive Development,"5.
} 
and in executive function. ${ }^{59}$ These cognitive skills are essential for many aspects of daily tasks, and therefore their deterioration has detrimental effects on the quality of life of older people. As we live in an ageing society, understanding the source of this cognitive decline and exploring potential avenues to improve cognition in older adults is apparently important and may have extensively applied implications.

Although less studied, ageing also affects emotional responses. Several investigators have shown that normal ageing leads to a positive emotional bias, ${ }^{60}$ though others have argued for an increased prevalence of anxiety disorders in the aged population. This increased anxiety is also reported to be associated with the extent of cognitive decline. The sources of these apparent contradicting findings concerning the affective response to ageing are unclear. Furthermore, there is a lack of research into the interplay between emotion and cognition in elderly individuals. This is of interest as emotional stimuli have been hypothesised to trigger a specific cognitive style which may modulate information processing. ${ }^{61}$

Emotional states and emotion-related stimuli are known to modulate the deployment of attention, ${ }^{62}$ with negative and positive emotions proposed to have opposite effects on the distribution of attentional resources. For example, there is evidence indicating that negative stimuli

59 Cheryl L. Grady, "Cognitive Neuroscience of Aging," The Year in Cognitive Neuroscience Annals of the New York Academy of Sciences, Vol. 1124 (2008), 128-130.

60 Katja Werheid et al., "Familiar Smiling Faces in Alzheimer's Disease," 2935-2940.

61 J. Storbeck \& G. L. Clore, "With Sadness Comes Accuracy: With Happiness, False Memory: Mood and the False Memory Effect," Psychological Science, Vol. 16 No. 10 (2005), 789.

${ }^{62}$ Storbeck \& Clore, "With Sadness Comes Accuracy", 790. 
capture attention in search displays when compared to neutral stimuli.

Thus, negative targets are detected faster, ${ }^{63}$ are stronger spatial attentional cues and increase attention to details. The effects of negative emotions on attention are increased in anxious individuals. Other work examining temporal aspects of attention, using an attentional blink paradigm, has shown that negative emotions lead to slower attentional disengagement and hence a lengthening of the 'blink' duration. ${ }^{64}$ These findings suggest that negative emotions are associated with a focused and relatively narrow attention spotlight in both time and space. On the other hand, positive emotions are recommended to have the reverse effect. Mather and Carstensen ${ }^{65}$ further found that attentional capture is biased towards positive stimuli in older adults: attention is directed to a definite expression rather than a neutral one, and to a neutral expression rather than a negative one.

Emotional stimuli types in Islam generally, and in Islamic psychospiritual specifically refers to command of Allah when the first revelation conveyed to Prophet Muhammad (PBUH) asking him to read or learn as in Surah al-"Alaq 96:1-4, means "Read in the name of your Lord Who created. He created man from a clot. Read and your Lord is Most Honourable, Who taught (to write) with the pen. Taught man what he knew not." Since Islam has placed knowledge as a vital thing for human being in managing life and ensuring the realization of their purpose of life, i.e. happiness in the world and in the hereafter, this study has

63 For example see Ohman, Flykt \& Esteves, "Emotion Drives Attention", 466-478.

64 For example see Ohman, Flykt \& Esteves, "Emotion Drives Attention", 475-476.

${ }^{65}$ M. Mather \& L. L. Carstensen, "Aging and Motivated Cognition: The Positivity Effect in Attention and Memory," Trends Cognitive Science Vol. 9 No. 10 (2005), 496-502. 
chosen the stimulus for determining emotional stimuli types something associated with the quest for knowledge. This chosen also based on the past review that older adults' attention corresponds easily to positive emotional stimuli that which might have a good impact on their intellect and emotions.

As mentioned above, three stimuluses based on cognitive organs have been recognised. These stimulus are the sensory organs (hiss) contains of seeing, hearing, smelling, touching and tasting, however, focus is only narrowed on seeing and hearing; the mind/intellect/cognitive ('aql) comprises of cognition, reasoning and insight, however, emphasis is only on memorising; and the heart (qalb) concentrates on contemplating. The Table 1 below show the positive emotional stimuli which is able to apply to older adults to look the impact on their attention and emotion.

Table 1: Islamic Psychospiritual Positive Emotional Stimuli on Intellect

\begin{tabular}{|c|c|c|c|}
\hline Stimulus & $\begin{array}{c}\text { Emotional } \\
\text { Stimuli Types }\end{array}$ & Stimuli & Effect on Intellect \\
\hline $\begin{array}{l}\text { Sensory } \\
\text { (hiss) }\end{array}$ & Seeing & $\begin{array}{l}\text { The signs of } \\
\text { Allah's powerful } \\
\text { by showing the } \\
\text { pictures/photos } \\
\text { of things mention } \\
\text { in the Qur'an: } \\
\text { - Beautiful } \\
\text { garden } \\
\text { - Flowing water } \\
\text { - Fruits } \\
\text { - Plants } \\
\text { - Flowers } \\
\text { - Landscape } \\
\text { - Happy face }\end{array}$ & $\begin{array}{l}\text { Who created the seven } \\
\text { heavens one above } \\
\text { another; you see no } \\
\text { incongruity in the creation } \\
\text { of the Beneficent Allah; } \\
\text { then look again, can you } \\
\text { see any disorder? (Al- } \\
\text { Qur'an, Surah al-Mulk } \\
67: 3 \text { ) } \\
\text { Most surely in the creation } \\
\text { of the heavens and the } \\
\text { earth and the alternation of } \\
\text { the night and the day, and } \\
\text { the ships that run in the sea } \\
\text { with that which profits }\end{array}$ \\
\hline
\end{tabular}




\begin{tabular}{|c|c|c|}
\hline & & $\begin{array}{l}\text { men, and the water that } \\
\text { Allah sends down from the } \\
\text { cloud, then gives life with } \\
\text { it to the earth after its } \\
\text { death and spreads in it all } \\
\text { (kinds of) animals, and the } \\
\text { changing of the winds and } \\
\text { the clouds made } \\
\text { subservient between the } \\
\text { heaven and the earth, there } \\
\text { are signs for a people who } \\
\text { understand. (al-Qur'an, } \\
\text { Surah al-Baqarah } 2: 164 \text { ) } \\
\text { Does one of you like that } \\
\text { he should have a garden of } \\
\text { palms and vines with } \\
\text { streams flowing beneath } \\
\text { it; he has in it all kinds of } \\
\text { fruits; and old age has } \\
\text { overtaken him and he has } \\
\text { weak offspring, when, } \\
\text { (lo!) a whirlwind with fire } \\
\text { in it smites it so it becomes } \\
\text { blasted; thus Allah makes } \\
\text { the communications clear } \\
\text { to you, that you may } \\
\text { reflect. (Al-Qur'an, Surah } \\
\text { al-Baqarah 2:266) }\end{array}$ \\
\hline Hearing & $\begin{array}{l}\text { - Recitation of al- } \\
\text { Qur'an; } \\
\text { - Qur'anic verses } \\
\text { on advice and } \\
\text { encouragement } \\
\text { (targhìb); } \\
\text { - Islamic songs } \\
(\text { anāshid) }\end{array}$ & $\begin{array}{l}\text { - The response of the } \\
\text { believers, when they } \\
\text { are invited to Allah and } \\
\text { His Messenger that he } \\
\text { may judge between } \\
\text { them, is only to say: We } \\
\text { hear, and we obey; and } \\
\text { these it is that are the }\end{array}$ \\
\hline
\end{tabular}




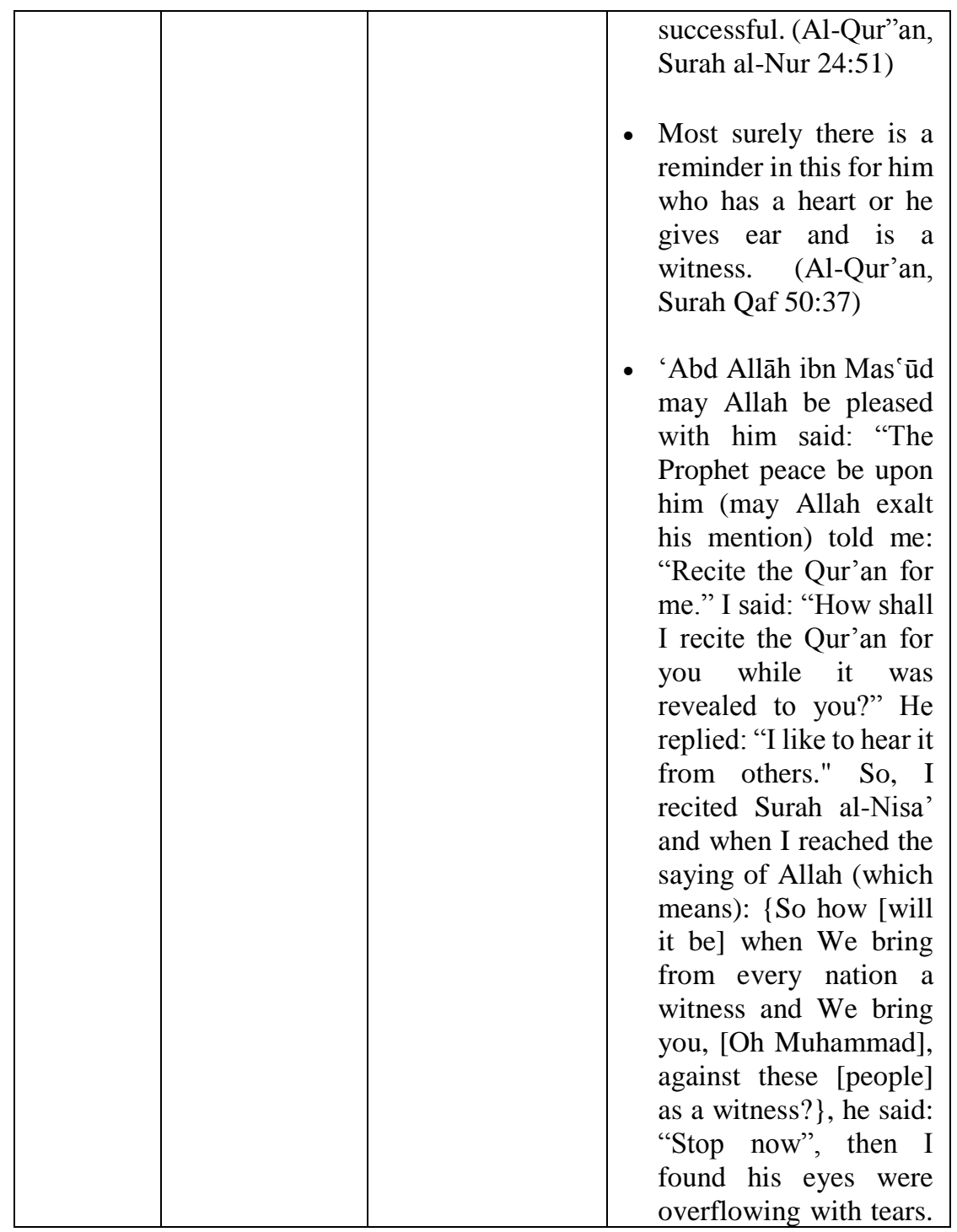


Che Zarrina, Nurul Salikin, Syed Mohammad \& Mohd Khairul Naim,

"Emotional Stimuli on Intellect Among Older Adults," Afkār Vol. 21 Issue 1

(2019): 163-198

\begin{tabular}{|c|c|c|c|}
\hline & & & $\begin{array}{ll}\text { Al-Bukhāri } & \& \\
\text { Muslim) }^{66} & \end{array}$ \\
\hline $\begin{array}{l}\text { Cognitive } \\
\text { ('aql) }\end{array}$ & Memorising & $\begin{array}{l}\text { - Repeating and } \\
\text { rehearsing the } \\
\text { Qur'anic verses }\end{array}$ & $\begin{array}{l}\text { - And certainly, We have } \\
\text { made the Quran easy } \\
\text { for remembrance, but is } \\
\text { there anyone who will } \\
\text { mind? (Al-Qur'an, } \\
\text { Surah al-Qamar 54:17) } \\
\text { - Do they not then reflect } \\
\text { on the Quran? Nay, on } \\
\text { the hearts there are } \\
\text { locks. (Al-Qur'an, } \\
\text { Muhammad 47:24) } \\
\text { - (It is) a Book We have } \\
\text { revealed to you } \\
\text { abounding in good that } \\
\text { they may ponder over } \\
\text { its verses, and that } \\
\text { those endowed with } \\
\text { understanding may be } \\
\text { mindful. (Al-Qur'an, } \\
\text { Surah Sad 38:29) }\end{array}$ \\
\hline $\begin{array}{l}\text { Heart } \\
(q a l b)\end{array}$ & Contemplating & $\begin{array}{l}\text { - Remembering } \\
\text { and repeating } \\
\text { Allah's names } \\
(\text { Dhikr Allāh) } \\
\text { - Reciting prayer } \\
\left(d u^{\prime} \bar{a}^{\prime}\right)\end{array}$ & $\begin{array}{l}\text { - Those who believe and } \\
\text { whose hearts are set at } \\
\text { rest by the } \\
\text { remembrance of Allah; } \\
\text { now surely by Allah's } \\
\text { remembrance are the } \\
\text { hearts set at rest. (Al- }\end{array}$ \\
\hline
\end{tabular}

${ }^{66}$ Abū 'Abd Allāh Muhammad bin Ismāeìl al-Bukhārī, Saḥiḥ al-Bukhārī, ed. Muḥammad Zuhayr bin Nāṣir al-Nāṣir, number 5050, vol. 1 (n.p.: Dar Tawq al-Najāh, 1422H), 298. 


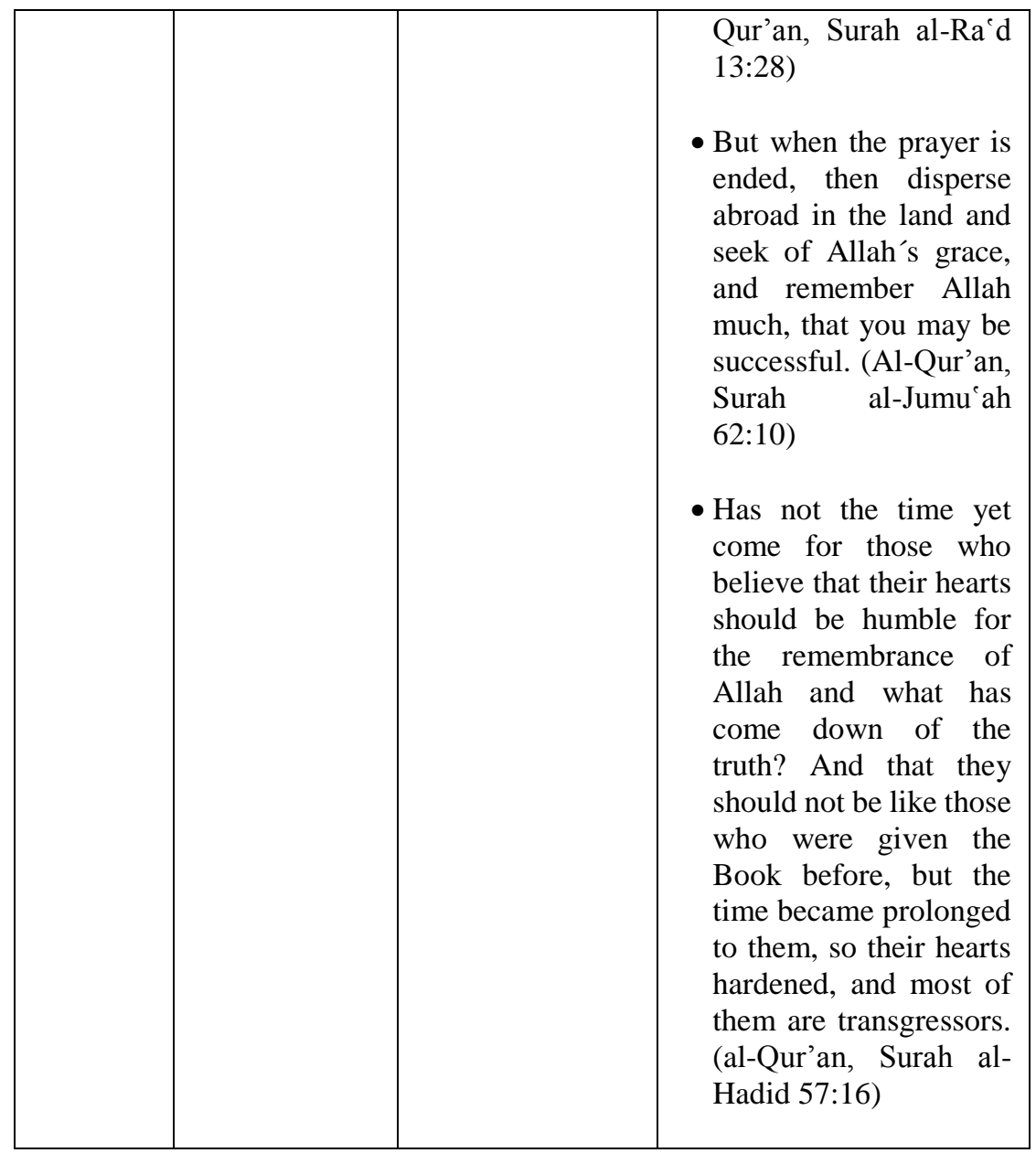

In Islamic tradition, the Holy Qur'an is the fundamental Holy Book of Islam encompassing 114 Chapters (Surah). Muslims have faith in the Qur'an as a reserve of great assistance and path for manhood with consideration of it as the ultimate revelation of God. Dealing with the Qur'an in everyday life is important especially those who are at the stage of old age. At this 
point, older adults are preparing for the end of their lives. Hence, those who are experiencing intellectual and emotional deterioration can be helped by applying these positive emotional stimuli which is based on their interaction with the Qur'an. According to Sarah et al., the brain controls the sensory organ. A major factor determining the success of the maturation process is the collection of enough auditory input. Thus, the experience gained through hearing will enhance brain functions and will prevent its declinations. ${ }^{67}$ This practice able to help older adults to sustain their good attention and emotion.

Memorizing Holy Qur'an by heart can be said as encoding, storing and retrieving the text of Qur'an by practising and reciting it, again and again. This process is known as hifz that involves first encoding the text of Qur'an by giving it attention, second storing it by maintaining the encoded information and then third retrieving the information from memory stores. ${ }^{68}$ As mentioned in Nawaz \& Jahangir work, past research studies revealed that memorising and continue challenging the brain can prevent memory loss as Alzheimer and dementia. In the process of memorizing the Qur'anic verses, men are required to memorize and to repeat and rehearse the text every day which results in a sharpening of memory. The more they memorise, the easier it becomes to memorise more. ${ }^{69}$ Reciting and repeating the names of Allah mindfulness everyday will give impact to the heart as Allah states in His verses. The practice by older adults will nurture the

67 Sarah Rahmat et al., "Hearing Impairment from the Islamic Perspective: A Review", IMJM Vol. 17 (Special Issue No. 2) (2018), 35-37.

68 Nazia Nawaz \& Syeda Farhana Jahangir, "Effects of Memorizing Quran by Heart (Hifz) on Later Academic Achievement," Journal of Islamic Studies and Culture Vol. 3 No. 1 (June 2015), 58.

${ }^{69}$ Nawaz \& Jahangir, "Effects of Memorizing Quran by Heart (Hifz) on Later Academic Achievement," 59. 
healthiness of their brain as what can be found in the activity of memorise the verses of the Qur'an.

This is an adage that practice makes older adults got impact for their cognition as it is for physical skills. This practice should be regular and extensive, and it is conforming Kostler finding where he reported that brain becomes more efficient as the person becomes a drilled reader. $^{70}$

\section{Conclusion}

In the Islamic tradition, men are required to execute the quest for knowledge from the beginning of their life until the old age. Men are not suggested to stop searching for knowledge as it involves strengthening the intelligence of faith and achieving the level of piety (taqwa) who at this stage as promised by Allah live in peaceful and satisfaction, thus they are able try to maintain their attention and emotion. The study concludes that the positive emotional stimuli play a vital role in nurturing older adults' intellect from Islamic psychospiritual fields. In Islamic tradition, visualising the signs of Allah's powerful, hearing the good verses, memorising the Qur'anic verses and reciting the dhikrullah and $d u^{\prime} a$ ' will lead to developing human intellect or cognitive and keep their heart in peace and tranquillity.

\section{Acknowledgment}

This research is sponsored by University of Malaya (UMRG RP028C-16HNE).

\section{References}

Addis, Donna Rose, Roberts, Reece P. \& Schacter, Daniel L., "Age-related Neural Changes in Autobiographical Remembering and Imagining," Neuropsychologia, Vol. 49 No. 13 (Nov 2011): 3656-3669.

70 Arthur Kostler, The Act of Creation (London: Hutchinson and co, 1964). 
Che Zarrina, Nurul Salikin, Syed Mohammad \& Mohd Khairul Naim, "Emotional Stimuli on Intellect Among Older Adults," Afkār Vol. 21 Issue 1

(2019): 163-198

Armstrong, Amatullah. Sufi Terminology (Al-Qamus alSufi). Lahore: Ferozsons, 2001.

Al-Attas, Syed Muhammad Naquib. Prolegomena to the Metaphysics: An Exposition of the Fundamental Element of the Worldview of Islam, 2nd ed. Kuala Lumpur: International Institute of Islamic Thought \& Civilization (ISTAC), 2001.

Barrett, L. F., "Are Emotions Natural Kinds?” Perspectives on Psychological Science, Vol. 1 No. 1 (2006): 28-58.

Barsalou, L. W., "Ideals, Central Tendency and Frequency of Instantiation as Determinants of Graded Structure in Types," Journal of Experimental Psychology: Learning, Memory, and Cognition, Vol. 11 No. 4 (1985): 629-654. Al-Bukhārí, Muhammad bin Ismā'ìl. Șahịh al-Bukhārí. Damascus: Dār Ibn Kathīr, 2002.

Commodari, Elena \& Guarnera, Maria. "Attention and Aging," Aging Clinical and Experimental Research, Vol. 20 No. 6 (December 2008): 578-584.

Crow, Karim Douglas, "The Intellect in Islamic Thought: Mind and Heart," KATHA: The Official Journal of the Centre for Civilisational Dialogue, Vol. 2 No. 1 (2006): 1-16

Dalhat, Yusuf. "The Concept of al-Aql (Reason) in Islam", Internatioal Journal of Humanities and Social Science, Vol. 5 No. 9(1) (September 2015): 77-83.

Davidson, R. J. and Irwin W., "The Functional Neuroanatomy of Emotion and Affective Style," Trends in Cognitive Science, Vol. 3 No. (1999): 11-21.

Ekman, P., "An Argument for Basic Emotions," Cognition and Emotion, Vol. 6(3/4) (1992): 169-200.

Ellsworth, P. C. and Scherer, K. R. "Appraisal Processes in Emotion". In Series in Affective Science: Handbook of Affective Sciences, eds. Davidson, R. J., Goldsmith, H. H. and Scherer, K. R. (New York: Oxford University Press, 2003): 572-595. 
Frijda, N. H. The Laws of Emotion. Mahwah, NJ: Lawrence Erlbaum Associates, Inc., 2007.

Al-Ghazālī al-Ṭūsī, Abū Hāmid Muhammad bin Muhammad. Ihyā Ulüm-Id-Dīn, trans. M. F. Karim, vol. 3. New Delhi: Islamic Book Services, 1995.

Grady, Cheryl L., "Cognitive Neuroscience of Aging," The Year in Cognitive Neuroscience Annals of the New York Academy of Sciences, Vol. 1124 (2008): 127-144.

Ibn Manẓūr, Lisān al- 'Arab, vol. 11. Beirut: Dār Șādir, $1414 \mathrm{H}$.

Kostler, Arthur. The Act of Creation. London: Hutchinson and Co. 1964.

Lavie, Nilli, "Attention, Distraction and Cognitive Control Under Load," Current Directions in Psychological Science, Vol. 19 No. 3 (June 2010): 143-148.

Mather, M. \& Carstensen, L. L. 2005. "Aging and Motivated Cognition: The Positivity Effect in Attention and Memory," Trends Cognitive Science Vol. 9 No. 10 (2005): 496-502.

Munsoor, Mohamed Safiullah \& Che Zarrina Saari, "Knowledge and Islam on the Non-Rational and Rational-Heart-Brain Inter-Connection", Journal of Aqidah and Islamic Thought (AFKAR), Vol. 19 No. 1 (2017): 129-162

Munsoor, Mohamed Safiullah. "The Soul (Heart) and Its Attributes: An Islamic Perspective with Reference to Self in Western Psychology," Journal of Aqidah and Islamic Thought (AFKAR), Vol. 16 (2015): 93-118.

Nabih Amin Faris (Trans. with Notes). Imam al-Ghazali, The Book of Knowledge. New Delhi: Islamic Book Services, 1991: 218-220.

Najātī, Muḥammad 'Uthmān. Al-Dirasāt al-Nafsāniyyah 'Ind al-'Ulamā' al-Muslimīn. Cairo: Dār al-Shuruq, 1993. 
Al-Nasā'i, Abū 'Abd al-Raḥmān Aḥmad bin Shu'īb. AlMujtabā min al-Sunan, ed. 'Abd al-Fattāḥ Abū Ghuddah, Ḥalab: Maktab al-Mațbū'āt al-Islāmiyyah, 1986.

Nawaz, Nazia \& Jahangir, Syeda Farhana, "Effects of Memorizing Quran by Heart (Hifz) on Later Academic Achievement," Journal of Islamic Studies and Culture, Vol. 3 No. 1 (June 2015): 58-64.

Niedenthal, P. M., Halberstadt, J. B. and Innes-Ker, A. H., "Emotional Response Categorization," Psychological Review, Vol. 106 No. 2 (1999): 337-361.

Nilli Lavie. "Distracted and Confused?: Selective Attention Under Load," Trends in Cognitive Sciences, Vol. 9, No. 2 (2005): 75-82.

Ohman, A., Flykt, A. and Esteves, F., "Emotion Drives Attention: Detecting the Snake in the Grass," Journal of Experimental Psychology: General, Vol. 130 No. 3 (2001): 466-478.

Panksepp, J. Affective Neuroscience: The Foundations of Human and Animal Emotions. New York: Oxford University Press, 1998.

Russell, J. A. and Fehr, B., "Relativity in the Perception of Emotion in Facial Expressions," Journal of Experimental Psychology: General, Vol. 116 No. 3 (1987): 223-237.

Sarah Rahmat et al., "Hearing Impairment from the Islamic Perspective: A Review," IMJM Vol. 17 (Special Issue No. 2) (2018): 35-47.

Scherer, K. R. "Emotion Serves to Decouple Stimulus and Response". In The Nature of Emotion: Fundamental Questions, ed. Ekman, P. and Davidson, R. J. New York: Oxford University Press. 1994: 127-130.

Schuon, Frithjof. Sufism: Veil and Quintessence, A New Translation with Selected Letters, ed. James Cutsinger. Bloomington, Indiana: World Wisdom, 2006. 
Shahar, Shulamith. Growing Old in the Middle Ages: Winter Clothes Us in Shadow and Pain. London and New York: Routledge, 2004.

Shehu, Salisu, "A Study of the Islamic Perspective of Cognitive Development and Its Implications in Education in the Muslim World," Revelation and Science, Vol. 5 No. 1 (2015): 1-9.

Smith, C. A. and Lazarus, R. S. "Emotion and Adaptation". In Handbook of Personality: Theory and Research, ed. Pervin, L. A. New York: Guilford Press, 1990: 609-637. Smith, Margaret. Al-Muhāsibi, An Early Mystic of Baghdad, translated and commentary by Margaret Smith. Lahore: Islamic Book Foundation, 1935.

Storbeck, J \& Clore, G. L., "With Sadness Comes Accuracy; With Happiness, False Memory: Mood and the False Memory Effect," Psychological Science, Vol. 16 No. 10 (2005): 785-791.

Werheid, Katja et al., "Familiar Smiling Faces in Alzheimer's Disease: Understanding the Positivityrelated Recognition Bias," Neuropsychologia, Vol. 49 No. 10 (Aug 2011): 2935-2940. 
Che Zarrina, Nurul Salikin, Syed Mohammad \& Mohd Khairul Naim, "Emotional Stimuli on Intellect Among Older Adults," Afkār Vol. 21 Issue 1 (2019): 163-198 